\title{
American Association for the Advancement of Science
}

\section{Atlantic City Meeting}

$\mathrm{T}^{\mathrm{H}}$ HE ninety-ninth meeting of the Association was held in Atlantic City, N.J., on December 28January 2, where one meeting had been held previously, namely, in 1932. This was to many of the members a strange setting for a great scientific assembly with the wide board-walk winding along close by the breakers of the Atlantic, and lined on the other side by shops in endless variety over which tower the great hotels, the comforts and service of which have made Atlantic City famous. One found no great university buildings, no richly stored museums, no famous research laboratories such as usually shelter the sessions and stimulate the activities of Association meetings. But all pronounced the meeting a success; the weather was mild, the sea beautiful, the attendance good, and the facilities adequate to serve well all needs of the occasion.

The splendid Municipal Auditorium, with numerous audience rooms of varied capacity, and the wellplanned meeting-places in the big hotels brought closer together than ever before the sessions of the fifteen sections and some forty associated societies and conferences included in the programme. Time spent in reaching distant meotings was saved, conferences were easily arranged, and personal contacts more frequent. Important as are the formal papers, one must rate of even higher value the discussions between and after meetings when new ideas are subjected to the keenest criticism. All conditions at Atlantic City contributed to further interchange of views and to strengthen the unity of the Association.

The opening general session on December 28 was devoted primarily to the address of the retiring president, Dr. Karl T. Compton, on "The Electron : Its Intellectual and Social Significance". Dr. Compton used the discovery of the electron, which apparently had no practical use when first found and measured, as the example of how pure research turns into valuable practical application. He enumerated industries made possible by electronic devices which have a total business of hundreds of millions of dollars each year, and added that the application of the discovery of the electron has brought intangible values in improved health, safety and convenience. Taking a swift audit of the electron's money contribution to civilization, Dr. Compton pointed out that it is responsible for a growing industry in electronic devices which now amounts to a total business of $50,000,000$ dollars a yoar in America alone.

The Sigma Xi address on December 29 was given by Dr. Henry G. Knight, chief of the U.S. Bureau of Chemistry and Soils, on "Selenium and Its Relation to Soil, Plants, Animals, and Public Health". The Phi Beta Kappa address on December 30 was delivered by President James R. Angell, of Yale University; his subject was "The Scholar and the Specialist".

Special afternoon general lectures were given on December 28 by Dr. E. O. Hulbert, of the Naval Research Laboratory, on "The Optics of the Surface of the Sea", on December 29 by Mr. David Dietz, science editor of the Scripps-Howard newspapers, on "Science and the American Press", and on
December 30 by Dr. P. W. Zimmerman, of the Boyce Thompson Institute for Plant Research, on "Response of Plants to Hormone-like Growth Substances". The last mentioned item was a formal presentation before the Association of the subject awarded the Association Prize at St. Louis last year.

The Section on Medical Sciences devoted four days to a continuing symposium on cancer, covering in series of invited papers by leaders in cancer research the position of various aspects of present-day investigation. The morning of December 29 was devoted to various types of radiation and their effects, and the afternoon to heredity and constitutional factors; the following morning and afternoon to induction, stimulation and inhibition of tumorous growths; and the morning of December 31 to the metabolism of cancerous tissue. On the afternoon of December 30 , Dr. C. C. Little, director of the Jackson Memorial Laboratory, gave the afternoon general lecture on the subject "The Social Significance of Cancer". A general lecture was given on January 1 by Dr. Walter Schiller, of the University of Vienna, on "Changes and Modifications in the Conception of Carcinoma". All told, this series constituted the most complete presentation of the cancer problem and the results of research in this field yet organized in the United States. The sessions were largely attended and the discussions prolonged.

Some new features were introduced into the programme at Atlantic City. Friday, January 1, was designated Association Day and devoted to general purposes. The morning was utilized for meetings of sectional committees, scientific boards and the Secretaries' Conference of the Association. In the afternoon was held a demonstration symposium on "The Moving Picture in the Service of Science". In one large auditorium Dr. William Beebe showed his reels on "Bathosphere Embryonic Eels", made under the auspices of the New York Zoological Society. Following this, Mr. Perry Burgess, president of the Leonard Wood Memorial, presented a sound movie of dramatic interest, "Miracles in the South Sea", portraying life in the leper colony in Culion, P.I. At the same time in a separate auditorium Prof. E. M. K. Geiling, of the University of Chicago, and Mr. L. L. Robbins illustrated "Whaling for Science" in a film showing habits of the cetacean and search for the hypophysis. "High Speod Motion Pictures of the Flight of Birds and of Bullets", a series of great interest, was shown by Dr. H. IS. Edgerton, of the Massachusetts Institute of Technology. A colour film entitled "A Health Educator with a Cine-Kodak in the Orient" was exhibited and described by Dr. C. E. Turner, of the Massachusetts Institute of Technology; he presented vividly the mode of life, problems of population and sanitation in those regions.

The closing event in Atlantic City was a special showing on Friday evening (January 1) of "The Human Adventure", an eight-reel talking picture sketching man's rise from savagery to civilization. The late Dr. James Henry Breasted, director of the Oriental Institute at the University of Chicago, had 
supervised personally the production of this film and the sound record was partly in his own voice.

On January 2 the Association moved to Philadelphia on invitation of the American Philosophical Society, and in its famous hall heard a programme on viruses and virus diseases. The first paper, by Dr. W. M. Stanley, included a survey of the work granted the Association Prize. After the luncheon, visiting members were taken to the Franklin Institute and the Academy of Natural Sciences, where scientific programmes had been arranged.

The newly elected president of the Association, Dr. George D. Birkhoff, recently made Dean of the Graduate School of Arts and Sciences at Harvard, where he has been professor of mathematics since 1919, presented before the mathematicians an important paper entitled "A Conceptual Theory of Atomic Structure". This paper, which gives physicists a clearer comprehension of the composition of matter, presents anew to modern thought fundamental ideas first advanced by the illustrious James Clerk Maxwell. It is interesting to recall that in $1926 \mathrm{Dr}$. Birkhoff was awarded the Association Prize of the Philadelphia meeting for his paper demonstrating that Schrödinger's fundamental wave equation, then recently published, could be reached on the basis of a conceptual theory of matter and electricity.

The Association prize for an outstanding contribution to science in the Atlantic City programme was given to Dr. W. M. Stanley, of the Rockefeller Institute for Medical Research, for his paper entitled "Crystalline Tobacco-Mosaic Virus Protein". After reporting his experiments and analysing their significance with thoroughness, he concluded his paper as follows :

"In view of the properties which this protein possesses, the borderline between the living and the non-living tends to become non-existent, for, although it possesses properties which have been regarded as characteristic of living things, such as specificity of host range and the ability to reproduce and to mutate, it is nevertheless a protein molecule and as such may be regarded as non-living. It is possible that by virtue of its size, it is enabled to possess sufficient organization within the molecule to endow it with such properties. As such, it would represent a link between the type of organization within the atom or molecule with which chemists have concerned themselves and the type of organization within the cell with which biologists have been concerned."

The attendance at Atlantic City was large, being variously estimated from four to five thousand, of which 2,400 were officially registered. At the various sessions fourteen hundred papers were presented. Despite the variety of these offerings, the audience rooms were filled to capacity. The scientific exhibition was especially well visited and its numerous exhibits attracted favourable comment. Special mention may be made the remarkable research exhibit of Dr. Irving Langmuir, the Nobel laureate in chemistry, who has produced the world's thinnest films.

The addresses of the retiring vice-presidents, given at various times, included the following:

Mathematics : Prof. T. H. Hildebrandt, of the University of Michigan, on "Recent Developments in the Theory of Integration"; Physics: Prof. John $T$. Tate, of the University of Minnesota, on "Electron Impacts in Gases"; Chemistry: Prof. Moses Bomberg, of the University of Michigan, on "Free Radicals"; Astronomy: Dr. H. R. Morgan, of the United States Naval Observatory, on "Some Problems in Fundamental Astronomy"; Zoology: Dr. Ross G. Harrison, of Yale University, on "Embryology and Its Relations"; Botany: Prof. E. W. Sinnott, of Columbia University, on "Morphology as a Dynamic Science"; Anthropology: N. C. Nelson, of the American Museum of Natural History, on "Prehistoric Archæology, Past, Present, and Future"; Psychology: Dr. Robert M. Ogden, of Cornell University, on "The Psychology of Art: Naive Geometry" ; Education : Prof. F. B. Knight, of the University of Iowa, on "Data Related to Classroom Learning" ; Social and Economic Sciences : Dr. Shelby Harrison, of the Russell Sage Foundation, on "Winning Social Advance Through the Process of Accretion"; Historical and Philological Sciences : Dr. George Sarton, of Harvard University, on "The Study of the History of 20th Century Science"; Agriculture: Prof. H. K. Hayes, of the University of Minnesota, on "Agricultural Research in China".

The following officers were elected for the terms indicated in parenthesis :

President (1937) : George D. Birkhoff, of Harvard University ;

Permanent Secretary (1937-40): Forrest R. Moulton, formerly professor of astronomy, University of Chicago ;

General Secretary (1937-40) : Otis W. Caldwell, of Boyce Thompson Institute for Plant Research;

Treasurer (1937-40): John L. Wirt;

Elected Council Members (1937-40): Vincent du Vigneaud, of George Washington University Medical School, and Sam F. Trelease, of Columbia University ; Members of the Executive Committee (1937-40): Edwin G. Conklin, of Princeton University, and Henry B. Ward, professor emeritus of the University of Illinois ;

Member of the Board of Trustees of Science Service (1937-39) : J. McKeen Cattell, editor of Science ;

Members of the Finance Committee (1937-40): Arthur Keith, of the United States Geological Survey, and (1937-38) Charles S. Baker, Munsey Building, Washington, D.C. ;

Members of the Committee on Grants (1937-40): A. T. Poffenberger, of Columbia University, and Jacob G. Lipman, of the New Jersey Agricultural Experiment Station;

Vice-Presidents of the Sections (1937):

W. D. Cairns, Oberlin College (Mathematics) ;

Harvey Fletcher, the Bell Telephone Laboratories (Physics) ;

Farrington Daniels, the University of Wisconsin (Chemistry) ;

Philip Fox, the Adler Planetarium and Astronomical Museum (Astronomy);

Kirtley F. Mather, Harvard University (Geology and Geography) ;

Ralph S. Lillie, the University of Chicago (Zoological Sciences) ;

F. E. Denny, the Boyce Thompson Institute for Plant Research (Botanical Sciences):

John R. Swanton, the United States Bureau of American Ethnology (Anthropology);

A. T. Poffenberger, Columbia University (Psychology);

Stuart Rice, United States Central Statistical Board (Social and Economic Sciences);

R. C. Archibald, Brown University (Historical and Philological Sciences); 
J. W. Barker, Columbia University (Engineering); Esmond R. Long, the University of Pennsylvania (Medical Sciences);

E. C. Auchter, the United States Bureau of Plant Industry (Agriculture) ;

Ralph Tyler, Ohio State University (Education).

Secretaries of the Sections (1937-40) :

E. R. Hedrick, the University of California at Los Angeles (Mathematies);

H. A. Barton, the American Institute of Physics (Physies) ;

Neil E. Gordon, of Johns Hopkins University (Chemistry).

Harlan T. Stetson, the Massachusetts Institute of Technology (Astronomy);

Howard Meyerhoff, Smith College (Geology and Geography) ;

George A. Baitsell, Yale University (Zoological Sciences) ;
J. T. Buchholz, the University of Illinois (Botanical Sciences) ;

W. M. Krogman, Western Reserve University (Anthropology);

Leonard Carmichael, the University of Rochester (Psychology);

E. P. Hutchinson, Il Centre Street, Cambridge, Mass. (Social and Economic Seiences);

Joseph Mayer, Library of Congress (Historical and Philological Sciences);

F. M. Feiker, the American Engineering Council (Engineering);

Malcolm Soule, the University of Michigan (Medical Sciences) ;

M. F. Morgan, the Connecticut Agricultural Experiment Station (Agriculture);

P. M. Symonds, Columbia University Teachers College (Education).

HENRY B. WARD.

\section{The Wellcome Trust}

$\mathrm{S}^{\mathrm{T}}$ R HENRY WELLCOME, who died on July 25, 1936, at the age of eighty-two years, was known as the creator of a great manufacturing business and also for the active interest he took in archæological and geographical exploration, the social welfare of native races and the promotion of fundamental research in sciences on which the progress of medicine depends. Beginning so long ago as 1894 , he founded in that year the Wellcome Physiological Research Laboratories, and two years later a corresponding centre for chemical research. In 1899, he established the Wellcome Tropical Research Laboratories at Khartoum, where the late Sir Andrew Balfour worked as director for twelve years, doing notable work on the control of malaria and the investigation of other tropical diseases. In 1913 the Wellcome Bureau of Scientific Research was brought into being to control the various research laboratories already operating, and then followed the Historical Medical Museum, the Museum of Medical Science and the Entomological Field Laboratory. All these institutions, with the exception of the physiological and entomological laboratories, are now housed in the magnificent Wellcome Research Institution in Euston Road, London. This was Sir Henry's crowning gift; the corner-stone was laid in 1931 by the late Lord Moynihan, who said that the ceremony might well be regarded as referring to the corner-stone of a long life's work.

By his will, Sir Henry provided for the continuance of the Wellcome Research Institution, the trustees appointed to administer the estate being Sir Henry Dale, F.R.S., director of the National Institute for Medical Research ; Prof. T. R. Elliott, C.B.E., F.R.S., professor of medicine in the University of London; Messrs. G. Hudson Lyall and L. C. Bullock, members of a London firm of solicitors; and Mr. Martin Price, chartered accountant.

The accompanying statement has now been issued by the five trustees :

As the trustees appointed by the will of the late Sir Henry Wellcome, we ask you to be good enough to publish this letter in order to clear up any misconception which may have arisen with regard to the effects of the will. We are led to make this state. ment by the number of appeals for contributions to various research undertakings which have already reached us. For reasons mentioned below the trustees will not be able to consider any such applications in the immediate future.

In January 1924 the Wellcome Foundation Limited was formed for the purpose of taking over the whole of the business activities of Burroughs Welleome and Co., and the various scientific research institutions and museums established by the late Sir Henry Wellcome, who held the whole of the share capital.

By the terms of the will the shares of the Welleome Foundation are now vested in us as trustees, and the activities of the Foundation throughout the world will be carried on, in collaboration with the trustees, by a Board of Directors of which the present Governing Director is Mr. George E. Pearson, who has been closely associated with the late Sir Henry Wellcome for more than forty years.

It will be realized that owing to the magnitude of the testator's estate, a very large sum has to be found for death duties. Provision has also to be made for :

(a) A welfare fund for the benefit of employees of the Wellcome Foundation Ltd., and its associated companies.

(b) The payment of certain specified annuities to relatives and others personally connected with the testator.

(c) The erection and maintenance of a building in Minnesota to be dedicated as a memorial to the testator's parents.

Subject to these prior charges, the remainder of the divisible profits will be utilized in accordance with the testator's instructions in the following manner :

(i) For the maintenance of "The Research Undertaking Charity", which is a fund for the advancement of medical and scientific research work in any part of the world conducive to the improvement of the physical conditions of mankind, and in particular for the discovery, invention and improvement of medicinal agents and methods for the prevention and cure of disorders, and the control or extermination of insect and other pests which afflict human beings and animal and plant life, and also for the organization, equipment and expenses of special research expeditions and commissions. 